\title{
Relações de trabalho dos jogadores profissionais de poker: do cotidiano de trabalho à saúde do jogador
}

\author{
Guilherme Elias da Silva', Francisco Hashimoto ${ }^{\text {II }}$ \\ ${ }^{1}$ Universidade Estadual de Maringá (Maringá, PR, Brasil) \\ ${ }^{\text {II }}$ Universidade Estadual Paulista, Faculdade de Ciências e Letras de Assis (Assis, SP, Brasil)
}

\begin{abstract}
O objetivo geral da pesquisa foi compreender as relações de trabalho dos jogadores profissionais de poker, à luz da Psicossociologia, a partir de um paralelo com as políticas de gestão desenvolvidas nas organizações estratégicas. A coleta de dados foi composta por entrevistas individuais e análise de obras autobiográficas de jogadores profissionais de poker. A discussão apresentada proporcionou um alerta frente à profissão que se encontra em amplo desenvolvimento e merece total cobertura, tanto em seus aspectos jurídicos, administrativos e contábeis quanto no sentido dos saberes relativos à saúde do trabalhador (como a Psicologia, a Medicina, a Fisioterapia, entre outros), visando instrumentalizar o desenvolvimento de melhores estruturas em relação às condições e à organização do trabalho, a fim de que os jogadores, que se empenham cotidianamente nesse exercício profissional, possam gozar de qualidade de vida e saúde no trabalho.
\end{abstract}

Palavras-chave: Poker, Jogo, Trabalho, Psicossociologia, Saúde.

Work relations of professional poker players: from daily work to player health

The overall objective of the research was, therefore, to understand the working relationship of professional poker players at the time of career recognition in the light of Psychosociology from a parallel with the management policies developed in strategic organizations. Data collection consisted of individual interviews and analysis of the works of professional poker players to elucidate the points that comprised the analysis proposed by the research objectives. The discussion presented by the research ends up being an alert across the profession that is in wide development and thus deserves full coverage both in their legal, administrative as well as its accounting aspects, and in the sense of knowledge committed to workers' health (such as medicine, psychology, physical therapy, etc.), aiming to equip the development of better structures in relation to the conditions and the organization of work, so that players who are engaged daily in the professional poker game exercise can enjoy a better quality of life and health

Keywords: Poker, Game, Work, Psychossocilogy, Health.

\section{Introdução}

Somos produtos (e produtores) da chamada sociedade pós-moderna, que apresenta como traços característicos o exibicionismo e o esvaziamento das trocas intersubjetivas. A hipótese defendida por diversos autores (Bauman, 1998, 2008; Birman, 2001; Freire-Costa, 2004a, 2004b; Harvey, 2007; Lasch, 1983) é que a fragmentação da subjetividade trouxe como reação o centramento do sujeito no eu (instância psíquica), porém de uma forma distinta do individualismo moderno. Se a subjetividade moderna constitui-se no registro da interioridade e da reflexão sobre si mesmo, a subjetividade contemporânea sustenta o paradoxo de um autocentramento voltado para a exterioridade, em que a dimensão estética dada pelo olhar do outro ganha destaque. $O$ terror narcísico é, portanto, o fato de ser comum, de não ser especial ${ }^{1}$

\footnotetext{
1 narcisismo, no contexto da presente exposição, é entendido como uma vertente do individualismo contemporâneo particularmente insensível a compromissos com ideais de conduta coletivamente orientados. Em consonância com Freire-Costa (2004b), o uso da palavra narcisismo em tal acepção representa satisfatoriamente o alicerce e o funcionamento moral da sociedade urbano-capitalista brasileira. Essa acepção não coincide com o que é utilizado na literatura técnica da psicanálise clássica, na qual narcisismo é a condição mental indispensável à aquisição de sentimento e da consciência de "identidade" subjetiva. Ou seja, o narcisismo, em psicanálise, representa um modo particular de relação com a sexualidade. É um conceito crucial no seu desenvolvimento teórico. O narcisismo é um protetor do psiquismo e um integrador da imagem corporal; ele investe o corpo e lhe
} 
Cada pessoa busca sentido e reconhecimento em sua vida e, especialmente, na atividade laboral; no entanto, essa busca dificilmente se completa, já que o sentido e o reconhecimento são ideais extremamente voláteis e transitórios nesta sociedade que prega a exigência de constante renovação. Essa busca por realização dentro das organizações é o que alimenta a competição desenfreada por mercados e também entre parceiros de trabalho, uma vez que o sistema estratégico nos faz crer que a felicidade pode ser alcançada nas malhas organizacionais - porém, não existe espaço nem oportunidade para todos. As organizações se tornam arenas onde cada indivíduo está envolvido em uma luta para encontrar um lugar e conservá-lo. Diante disso, Gaulejac (2007) afirma que habitamos um mundo que está contaminado pelo "realismo gestionário" e gera enorme impotência para desenhar os contornos de uma sociedade harmoniosa e preocupada com o bem comum.

A elucidação da estrutura das chamadas organizações estratégicas e das relações estabelecidas nesse campo é relevante para nossa discussão, já que tal modelo estratégico de administração é uma das principais ferramentas do capitalismo monopolista-financeiro. As organizações estratégicas desenvolvem métodos políticos de administração à distância (gestão afetiva de captura psíquica), difundem uma ideologia, uma religião da empresa e, desse modo, conseguem uma adesão fiel de seus membros por meio da influência sobre estruturas inconscientes da personalidade deles (Pagès, Bonetti, Gaulejac, \& Descendre, 1987).

O modelo de organização estratégica aparece, assim, como um novo ícone, uma nova referência, prometendo escoltar o sujeito na sua solidão e acompanhá-lo e conduzi-lo em seu sucesso, indo ao encontro de suas carências latentes e reduzindo a importância do vínculo social a um laço (financeiro, moral, ideológico e psicológico) com ela. Oferece, desse modo, oportunidades cômodas de identificação, ou seja, de assumir uma identidade compacta e objetivada, pretexto para expressar seu narcisismo.

Essa organização desenvolve um modelo de gestão que se vale da mobilização do que, em psicanálise, é denominado de ideal de Eu. Trata-se daquilo que temos de alcançar de qualquer modo para nos sentirmos "completos", perfeitos, onipotentes. A dinâmica do ideal de Eu é, de acordo com Gaulejac (2007), “...uma verve compulsória: não existe 'plano B' em relação a ele: ou o indivíduo o conquista, ou está fadado à angústia da falta, do vazio" (p. 15). Pergunta-se, porém: como a organização engendra essa dinâmica de ideal de Eu em seu sistema de gestão? Pela "promessa"! Mas promessa de quê? Pela promessa de que, se você tiver determinada coisa ou se você for determinada pessoa, você estará realizado. Essa promessa sedutora, cativante e confortante contribui para que, em momentos de incerteza, carência ideológica e desfiliação (enfraquecimento das instituições familiares e religiosas, do Estado, da nacionalidade/patriotismo e de instituições escolares), o indivíduo encontre espaço e referencial para organizar seus desejos e experimentar um falso gozo narcísico. As organizações necessitam, por conseguinte, de indivíduos sutis, capazes de tomar iniciativas e de reagir o mais rápido possível, dando provas de leveza e de flexibilidade diante dos acontecimentos imprevisíveis, constantes e numerosos com os quais são confrontados. Todo o mundo se torna um jogador, tentando ganhar e devendo obter sucesso, mesmo nas piores condições.

O artigo aqui proposto visa estabelecer uma associação entre as relações de trabalho que se estruturam nas organizações estratégicas no mundo contemporâneo e o funcionamento social e até mesmo patológico que se desenvolve nesses espaços institucionais com outro fenômeno social, que é o jogo de poker, que se popularizou principalmente na última década em todo o mundo. A proposta de analisarmos as relações de trabalho dos jogadores profissionais de poker - os modos de vida desenvolvidos nesse mundo de trabalho - torna-se promissora caso vislumbradas em paralelo às relações de trabalho desenvolvidas em organizações com modos de gestão estratégica, uma vez que ambos revelam-se como fenômenos sociais com processos de

dá dimensões, proporções e a possibilidade de uma identidade, de um Eu. O narcisismo ultrapassa o autoerotismo e fornece a integração de uma figura positiva e diferenciada do outro (para maior aprofundamento em relação ao conceito, ver Freud, 1914/1996). 
subjetivação característicos, que permitem uma leitura das feições psíquicas, éticas e ideológicas que compõem nossa sociedade.

Hoje em dia, o mercado de poker cresce aproximadamente $20 \%$ ao ano, tanto em faturamento quanto em número de novos jogadores e oportunidades de emprego. Pesquisas realizadas pelos dois maiores sites de poker (www.pokerstars.com.br e www.fulltiltpoker.com/pt) constataram que, em 2009, o número total de jogadores de poker no mundo era de 40 milhões e de poker on-line, 15 milhões, sendo que $23 \%$ dessas pessoas estavam nos EUA. Só no Brasil, acredita-se que esse número atualmente já chegue a mais de 5 milhões de pessoas ${ }^{2}$, o que possibilita calcular o tamanho da oportunidade para quem quer ingressar nesse mercado.

A oportunidade não está somente em se tornar jogador profissional de poker, mas também em se tornar dealer ${ }^{3}$, diretor de torneio, floorman ${ }^{4}$, montar um site, lançar uma revista, uma marca de roupas etc. São inúmeras as possibilidades no momento e o mercado não dá nenhum sinal de que esse ritmo vertiginoso de crescimento cessará brevemente. Novos e grandes investimentos são feitos no mundo inteiro para se promover o poker, tanto ao vivo quanto on-line. Todos os meses, novos mercados regulamentam as atividades e, em 2013, os EUA, conhecidos como o "gigante do mundo do poker", aprovaram $100 \%$ a prática on-line de poker novamente, o que gera um boom não somente lá, mas em todos os lugares do mundo por reflexo.

Diante desse cenário de desenvolvimento, ocorrido especialmente nos últimos dez anos, diversas pessoas passaram a converter o hobby em uma oportunidade de trabalho como jogador profissional. Alimentados pela ambição de uma fonte de renda expressiva e pela realização de outros sonhos, como liberdade na organização do próprio trabalho, viagens, exposição social, entre outros, um número cada vez maior de indivíduos se vê estimulado a empreender nessa nova profissão.

Em vista disso, buscamos compreender como se configura a construção desse fenômeno, que visa converter uma atividade que promoveria (e ainda, de certo modo, promove) aversão social, atrelada à destrutividade "intrínseca" ao jogo de azar, em prática lúdica e esportiva; e, em uma nova transformação, convertendo uma possível atuação desinteressada e trivial em atividade passível de empenho racional e técnico que permita uma atuação laboral a partir do exercício desse esporte da mente.

O objetivo geral da pesquisa foi, portanto, compreender as relações de trabalho dos jogadores profissionais de poker à luz da Psicossociologia, a partir de um paralelo com as políticas de gestão e consequentes configurações das relações de trabalho desenvolvidas nas organizações estratégicas. Os objetivos específicos foram: compreender como se estruturam as relações de trabalho dos jogadores profissionais de poker e elucidar o sofrimento no trabalho e como se configura a dinâmica saúde-doença dos jogadores profissionais de poker.

Esta pesquisa fundamentou-se teórico-metodologicamente na abordagem da Psicossociologia, que se interessa pelo indivíduo em situação, circunstância, ou seja, recusa-se a separar o indivíduo e o coletivo, o afetivo e o institucional, os processos inconscientes e os processos sociais para a análise das relações de trabalho que se desenvolvem nos diversos cenários.

A Psicossociologia trabalha com as relações entre o social (suas dimensões emocionais, subjetivas, afetivas e inconscientes) e o psiquismo (aqui compreendido como "modelado" pela cultura, língua e pela sociedade), introduzindo um questionamento fenomenológico sobre "...o

\footnotetext{
2 Dados cedidos pela Confederação Brasileira de Texas Hold'em - órgão máximo representante da categoria esportiva no país cadastrado no Ministério dos Esportes.

3 Dealer: o profissional responsável por distribuir as cartas.

4 Floorman: Um empregado de uma sala de poker que faz as leis e toma decisões.
} 
sujeito e a sua historicidade, isto é, sobre as capacidades e as resistências que conduzem os indivíduos e os grupos a produzirem a sua história, a quererem mudar o mundo e a operarem mudanças neles próprios" (Gaulejac, 2001, p. 37).

A coleta de dados foi composta por entrevistas individuais com três jogadores profissionais de poker ${ }^{5}$ adidos pelos dados contidos em obras com caráter autobiográfico de três outros jogadores, a saber: a) O poker como negócio: onde termina o hobby e começa o negócio, de Dusty Schmidt; b) Poker: a essência do Texas Hold'em: estratégias para se tornar um vencedor, de Carlos Mavca; e c) Como ganhei milhões jogando no WSOP, de Annie Duke, visando elucidar os pontos que compreendam a análise proposta pelos objetivos da pesquisa ${ }^{6}$.

A entrevista é uma ferramenta basal do método clínico e é, portanto, uma técnica de investigação científica em Psicologia. A entrevista psicológica seguiu a abordagem aberta, ou seja, o entrevistador teve liberdade para realizar as perguntas ou para fazer suas intervenções, permitindo assim toda a flexibilidade necessária em cada caso particular. No entanto, devemos sublinhar que:

.... liberdade do entrevistador, no caso da entrevista aberta, reside numa flexibilidade suficiente para permitir, na medida do possível, que o entrevistado configure o campo da entrevista segundo sua estrutura psicológica particular, ou - dito de outra maneira - que o campo da entrevista se configure, o máximo possível, pelas variáveis que dependem da personalidade do entrevistado (Bleger, 1998, p. 3).

De acordo com Mendes (2007), é importante a concentração e o envolvimento emocional, não colocando o sujeito da pesquisa na condição de objeto. Desse modo, o pesquisador assumiu uma atitude clínica. Tal atitude implicou priorizar a lógica do entrevistado, centrando-se na relação subjetiva dele com o objeto do discurso - no caso, a organização do trabalho com o jogo de poker, prazer-sofrimento (intrínseco nas relações de competitividade, risco, as condições de trabalho, ganhos-perdas, informalidade, estigma social etc.), as mediações, os processos subjetivos e intersubjetivos e o processo saúde-adoecimento.

5 A pesquisa foi aprovada pelo comitê de ética em pesquisa com seres humanos: CAAE n. 04992712.7.0000.5401.

6 Descrição dos jogadores entrevistados e dos autores dos livros que foram fontes de informações para a análise:

Entrevistado 1: Formado em Administração e ex-empresário do ramo de eventos. Passou a jogar profissionalmente em 2007 e, em 2008 e 2009, foi eleito o melhor brasileiro na modalidade "sit and go" online. No ano de 2010 foi eleito - a partir de seus resultados - o melhor do mundo na modalidade.

Entrevistado 2: Formado em Educação Física. Joga poker profissionalmente desde 2006. Exerce o poker online, mas tem sua principal fonte de renda advinda dos jogos ao vivo em clubes de poker na cidade de São Paulo e, especialmente, de premiações provenientes de campeonatos no circuito latino-americano.

Entrevistado 3: Cursou Administração na Fundação Getúlio Vargas. Em 2006 passou a se dedicar ao poker como jogador profissional, tendo conseguido resultados bastante expressivos tanto no poker ao vivo quanto no online.

Annie Duke: Norte-americana vencedora de 1 bracelete da WSOP; é uma das jogadoras de poker mais famosas do esporte. Duke nasceu em Concord, New Hampshire - EUA e graduou-se em Psicologia, chegando a exercer, por alguns anos, a carreira acadêmica. Joga desde 1996. O ano de 2010 foi ótimo para Duke. No início do ano, ela venceu o NBC National Heads-up Poker Championship 2010, derrubando 64 jogadores. Em 2010 ela também ganhou 2 milhões de dólares no inaugural World Series of Poker - Tournament of Champions. Na época, esta vitória lhe rendeu o maior prêmio em dinheiro pago em um único evento para um jogador de poker feminino. Duke ganhou um bracelete da World Series Poker, em Omaha HiLo, e mais de três milhões de dólares em torneios.

Dusty Schmidt: Norte-americano formado em Administração. Ex-jogador profissional de golf. Teve que abandonar a carreira devido a um ataque cardíaco. Trabalhou na empresa de seu pai, mas em 2006 entra profissionalmente no poker online. Em nove anos de carreira já acumula mais de seis milhões de dólares em ganhos e nunca teve um mês de perdas. Jogador com status de SuperNova Elite no site do PokerStars.

Carlos Mavca: Cursou economia na UFRJ e Jornalismo na UERJ. Ex-empresário do ramo alimentício, conheceu o Texas Hold'em em 2006 e hoje é um dos principais jogadores brasileiros de poker ao vivo. Estudioso das teorias do jogo, ele tem experiências nos clubes cariocas e ajuda a administrar o Clube Ases do Poker, considerado por muitos o berço dos principais jogadores do Rio de Janeiro. O autor é Bicampeão Niteroiense e conquistou o título de Campeão Estadual do Rio de Janeiro de 2009. Iniciou-se em torneios internacionais em 2010 e acumula inúmeras premiações online. Mavca conquistou uma série de eventos no Rio de Janeiro no cenário ao vivo e ainda tem um programa de treinamento destinado a iniciantes. 
O exame das entrevistas realizadas transcorreu a partir do processo de Análise dos Núcleos de Sentido (ANS). Esta consiste no desmembramento do texto em unidades, em núcleos de sentido formados a partir da investigação dos temas psicológicos sobressalentes do discurso. É aplicada por meio de procedimentos sistemáticos, que envolvem definição de critérios para análise e tem a finalidade de agrupar o conteúdo latente e manifesto do texto, com base em temas constitutivos de um núcleo de sentido, em definições que deem maior suporte às interpretações. A partir desta análise foram definidos três núcleos de sentido que nortearam a discussão do trabalho visando à consecução dos objetivos propostos, a saber: 0 cotidiano de trabalho como jogador profissional de poker, a socialização pelo jogo profissional e saúde no trabalho para o jogador profissional de poker.

\section{O cotidiano de trabalho como jogador profissional de poker}

"Matt pronuncia as palavras que dão o chute inicial em qualquer torneio, abrindo um mundo de possibilidades para cada um dos jogadores: 'Embaralhem e distribuam”' (Duke, 2007, p. 17). Na realidade que se configura no mundo do poker, esse pontapé abre um cenário possível para que o sujeito busque a realização de suas fantasias, locus onde ele possa exercer poder, desenvolver a socialização e sazonalmente obter reconhecimento, e, todavia, obviamente, ser antiteticamente o cenário favorecedor da frustração e da morte subjetiva.

Consonantemente à máxima do mercado, no jogo também vigora o imperativo de que não há lugar para todos e que o pódio é limitado aos de melhor desempenho. Os mais fortes devem resistir a um cenário animalesco para obterem sucesso na seleção (a)natural proposta.

O jogador Carlos Mavca (2011) alerta que, ao entrar para o mundo do poker, “...não espere ajuda ou misericórdia. Se demonstrar fraqueza, será atacado. Assim como você deve saber atacar os mais fracos" (p. 124). Dusty Schmidt (2012) reafirma e legitima esse processo apresentando uma verdade universal no poker: "...os seus oponentes mais fracos são os seus melhores fregueses" (p. 115). A naturalização e obrigação do sucesso se configuram em um campo de relações de poder desiguais, de modo que perversamente eu possa me favorecer dessas vantagens e alcançar o gozo a partir de uma opressão "sádica".

...o jogo de poker assemelha-se ao mundo dos negócios: as habilidades para se tornar um bom jogador de poker são as mesmas essenciais para ser bem sucedido no mundo competitivo. Neste sentido, você aproveita das suas percepções e intuições, das fraquezas dos adversários, das instabilidades emocionais, do humor dos jogadores da mesa. Você consegue induzir seus adversários a desistirem da rodada com as melhores mãos, fazendo-os jogar com a emoção, e até mesmo fazê-los "entrar em tilt" ao mostrar suas cartas, revelando que fez um grande blefe (Bello, 2008, p. 58).

Outro depoimento complementa e exemplifica esse campo opressivo e extorsivo que se desenvolve na ética do jogo:

No momento em que tiver entrado na mente de seu adversário e perceber que ele entrou em tilt, por alguma razão, você deve entender os motivos de ele ainda estar ali jogando, e atacar seus pontos fracos sem piedade para maximizar seus lucros. Se não o fizer, alguém irá fazê-lo (Mavca, 2011, p. 143).

No modelo de gestão que utilizaremos como paralelo - o gerenciamento estratégico -, vemos favorecer relações de violência, de exclusão e ostracismo. Na organização estratégica, todo mundo encontra-se submetido à tensão, ou seja, a uma pressão permanente que não conseguem controlar. Dessa forma, cada indivíduo tenta descarregar sua agressividade sobre o outro, contribuindo, assim, para reforçar a lógica do "salve-se quem puder", o que Gaulejac (2007) denominou de moral do assédio. Exemplo disso pode ser visto no relato de Duke (2007):

Phil é melhor jogador do que eu, mas, se for pego no momento certo, pode perder sua estabilidade. Parte da sua estratégia está voltada para deixar seus oponentes irritados. Ele 
insulta, caçoa do seu modo de jogar. A maioria deles se deixa levar pela tática e entra na defensiva, o que prejudica seu jogo. Tentam se vingar de Phil e, por excesso de agressividade impensada, perdem muito dinheiro para ele (p. 221).

Essa moralidade desenvolve-se no cenário empresarial, bem como nas relações profissionais que se descortinam nas mesas em que os sujeitos exercem seus ofícios.

\section{Jornada de trabalho}

Os jogadores profissionais organizam-se de modo a terem uma rotina de jogos estruturada cotidianamente. Os profissionais, de acordo com as entrevistas e obras de referência, geralmente apresentam jornada de trabalho de 5 a 6 dias por semana, sendo jogadas em torno de 8 a 10 horas nos dias de trabalho em questão. Apesar de ser um trabalho autônomo e permitir uma organização bem flexível (logo que, especialmente na internet, existem jogos 24 horas por dia), os jogadores devem estruturar-se em relação ao tempo dedicado ao trabalho e estudo do jogo. Dusty Schmidt dá algumas sugestões do regramento necessário e sustenta suas orientações com um tom altamente racional:

Cada vez que você se sentar para jogar poker, deve ser um exercício de reunir as horas de maior qualidade possível. Quando você não estiver praticando o seu melhor jogo, ou passar tempo praticando o jogo errado, ou em uma mesa que não seja produtiva, você está desperdiçando horas. Se você for um bom jogador, ganhando cinco big blinds a cada 100, sempre que comete um erro descuidado, e se custar cinco big blinds, perde uma hora da sua vida que você nunca terá de volta. Você basicamente precisa ver o seu tempo como se estivesse ganhando por hora. Não é excitante pensar no poker desta forma, mas esta é a verdade. Alguns dias você está pensando claramente, e os jogos são bons, então você ganha $\$ 1.000$ por hora em circunstâncias ideais. Outros dias podem não funcionar tão bem, e nestes dias você pode perder $\$ 500$ por hora. No geral, a sua média é de $\$ 250$ por hora. Então, se você passar 30 minutos assistindo um seriado cômico na TV enquanto deveria estar jogando, você está pagando $\$ 125$ para fazer isso. Os 10 minutos que você passa lendo um fórum idiota na internet lhe custam $\$ 42$ (1/6 de $\$ 250)$. Vejo o meu negócio de poker exatamente nestes termos. Se estiver fazendo algo a mais durante o tempo que reservei para jogar, isso está me custando dinheiro. Mas você tem que ser adaptável. (...) Talvez transforme o dia em uma maratona se o jogo continuar bom, ou apenas jogue até que as mesas deixem de ser boas. Se os jogos forem bons, colarei minhas pálpebras abertas se isso me mantiver nas mesas. Novamente, se você tiver a habilidade que lhe dê uma vantagem em um nível específico, precisa jogar o suficiente para tornar esta vantagem estatisticamente significativa. Por exemplo, se em condições normais, digamos que você ganhe $55 \%$ das suas mãos, e perca $45 \%$. Este gap de 10\% entre as suas vitórias e derrotas representa o seu lucro. Quanto este lucro irá crescer, depende de quanto você jogar. Este é o seu próprio negócio e, como tal, você não terá um chefe lhe dizendo a que hora você tem que estar lá e a que hora pode sair. A maioria das pessoas tem dificuldade com isso - se você jogar 40 horas por semana, é um monstro na indústria do poker (Schmidt, 2011, pp. 40-41).

Diante da questão de o lucro estar relacionada diretamente ao nível de imersão do indivíduo e às horas empenhadas por esse trabalhador, podemos nos questionar: será que nossa sociedade, dando a falsa impressão de controle sobre a jornada de trabalho do jogador de poker por parte de um exercício autônomo, na verdade, por outro lado, não levaria a um descontrole? Essa pergunta se faz plausível logo que a nossa sociedade está calcada nos princípios da ambição desmedida e da insatisfação constante. Vejamos o que isso pode reverberar em relação à organização do trabalho: “...se você jogar em tempo integral por 2-3 anos, terá visto tantas das mesmas situações que as suas decisões se tornarão, na maioria, automáticas. Uma vez que as decisões se tornem automáticas, você gastará menos tempo, o que lhe dará liberdade de adicionar ainda mais mesas" (Schmidt, 2012, p. 74).

Dando continuidade ao raciocínio da imersão do sujeito na atividade de trabalho, vejamos como o insaciado se estabelece atrelado às mediações sedutoras providas pela "organização-poker": 
...se aprendi algo nos últimos anos é que nada é certo. Bolsas quebram, negócios vão à falência, e trabalhos integrais podem desaparecer em função de demissões e cortes de orçamento. Uma vez que você entenda que o poker é uma coisa tão certa quanto qualquer outro emprego, é ótimo se sentar e considerar pontos positivos de ser um jogador de poker profissional. A felicidade na carreira é fundamental para o sucesso a longo prazo; se você gostar de poker, irá se esforçar mais, jogar por mais tempo, e ter mais sucesso com um sorriso no rosto ao final do mês - na maioria das vezes. A flexibilidade no horário, ser capaz de trabalhar em casa e ser o seu próprio chefe, são luxos que a maioria das pessoas não tem (Schmidt, 2012, p. 104).

As características do trabalho que são tidas como vantagens/“luxos" será que não podem ser, pelo contrário, grandes armadilhas? De acordo com Pagès et al. (1987), nos modelos de gestão estratégicos, é na submissão, na sobrecarga, na alienação que os trabalhadores encontram a fantasia de liberdade e o gozo narcísico. Na fala dos trabalhadores entrevistados podemos notar isso:

É necessário ter um ritmo muito mais rápido e ocupar-se de muitas coisas ao mesmo tempo... Trabalhamos muito mais que quarenta e cinco horas por semana... Isto faz parte do jogo, não é uma regra explícita, é implícita e depois admitimos ou não... Eu não discuto estes problemas (carga de trabalho). Eles estão aí, joga-se o jogo. Se não estamos de acordo, não jogamos. Uma vez que compreendemos as regras do jogo na TLTX e que as aceitamos, creio que devemos jogar o jogo (Pagès et al., 1987, p. 58, grifos dos autores).

Estas citações indicam que, se não se aceita a regra do jogo, deve-se ir embora. A organização dá a ilusão de uma liberdade de escolha. A liberdade que o trabalhador tem em uma sociedade capitalista de escolher seu local de exercício, todavia, ainda é necessário que ele seja aceito pela organização - correspondendo doutrinariamente às suas expectativas.

Configura-se, portanto, um cenário de longas jornadas de trabalho, o afastamento da vida privada e, ainda por cima, a necessária alegria e regozijo por estar nessa situação:

Entrevistado 2: Em muitos períodos do ano eu fico muito mais com a galera do poker do que com a minha família. Por exemplo, em abril e maio foi um evento atrás do outro. Seis semanas direto. Eu só fui pra casa pra trocar de roupa, pegar outra mala. Foi Foz do Iguaçu, depois São Paulo, depois um cruzeiro, depois Chile...

Nas organizações estratégicas, aquele que se conforma ao modelo de personalidade suscitado por elas (uma personalidade individualista e agressiva, porém adaptável, possuindo um ideal de perfeição e resistente ao estresse) encontra nesse cenário uma fonte de satisfação e de valorização narcisista muito importante, satisfações que, de acordo com Pagès et al. (1987), justificam a aceitação das pressões exercidas especialmente pela carga de trabalho. Quanto maior a satisfação, maior o nível de aceitação dessa carga e quanto mais poderosa for a organização, maior satisfação ela trará aos que se identificam com ela. Sendo assim, a adesão aos objetivos é o ponto-chave das relações no trabalho: “....a nossa 'liberdade' é maior quando nos 'submetemos"' (Pagès et al.,1987, p. 58).

Entretanto, nessa ocasião, fica evidente o paradoxo do "controle-vulnerabilizante": Mas a partir do momento em que adotamos a regra do jogo corremos o risco de não mais dominá-lo: somos possuídos. Eu jogo porque é preciso, afinal a gente tem de fazer uma escolha, eu jogo a fundo: me entrego ao jogo. Por enquanto eu sei dar marcha ré e me divirto, talvez eu ria porque tenho medo, ai, ai... (Pagès et al., 1987, p. 58).

"Dominar as regras do jogo" não nos habilita, necessariamente, a "dominar o jogo".

Aqueles que vivem disso já o sabem, mas é importante que todos entendam que a vida de um grinder ${ }^{7}$, jogando cerca de 8 a 10 horas por dia, 5 a 6 dias por semana, não é glamorosa como pensam por aí (...) Quando abandonamos nossas atividades e trabalho, convencemos nossa família sobre nosso novo projeto e falamos das maravilhas de se viver disso, de ser nosso próprio chefe e de fazer nosso próprio horário, nos enganamos um pouco. Talvez, no afã de convencer os outros, acabemos não enxergando que não é exatamente um trabalho dos sonhos como

7 Grinder: jogador que joga muitas horas por dia e muitas mesas simultaneamente (online). 
parecia. Os iniciantes, entusiasmados pelo jogo desde que começaram a jogar e ofuscados pelo glamour dos altos prêmios anunciados em torneios, acabam negligenciando o sacrifício que deve ser uma rotina de torneios e a variância no bankroll ${ }^{8}$ que isso pode acarretar (Mavca, 2011, p. 124).

Desse modo, os sujeitos imersos nesse mundo começam a se conscientizar do processo por eles vivenciado quando já estão, muitas vezes, atolados na areia movediça que é terreno nas relações de produção aí organizadas. Quanto mais se movimentam, mais ficam submersos, presos à ideologia.

\section{Alguns questionamentos críticos relativos às fantasias criadas em torno do endeusamento da profissão poker}

Em relação à assertiva de que "...os jogadores tem a autonomia de fazerem seus próprios horários de trabalho", Mavca afirma categoricamente: "MENTIRA!". Dois argumentos apresentados por ele dão solidez ao seu tom peremptório:

A. Os horários não são flexíveis. Para grindar torneios de verdade, você precisa ter uma rotina dura. Você não pode escolher jogar às $11 \mathrm{~h} 15$ ou às $19 \mathrm{~h} 45$ se aquele torneio com $100 \mathrm{k}$ garantido só começa às $21 \mathrm{~h}$. Além disso, você não pode começar o torneio às $21 \mathrm{~h}$ e parar às $23 \mathrm{~h}$ para sair com a mulher ou namorada. Terá que seguir até o fim. Você não pode jogar futebol com os amigos na terça-feira à noite, pois temos o satélite para tal evento, ou ir ao Maracanã aos domingos e perder os torneios principais de domingo (Mavca, 2011, p. 124).

O trabalho em turnos e/ou noturno é tema de relevância na atualidade, devido à sua ampla aplicação, por razões técnicas, sociais e econômicas. Entretanto, estudos (Moreno, Fisher, \& Rotenberg, 2003; Campos \& Martino, 2004; Oliveira, Berthoud, Begliomini, Coppola, \& Rangel, 2006) têm demonstrado que essa organização temporal do trabalho pode ocasionar distúrbios na saúde e perturbações na vida familiar e social do indivíduo.

B. Devido a esses horários totalmente irregulares e às durações imprevisíveis dos torneios, o jogador poderá dormir e acordar em horários diferentes ao longo de uma mesma semana ou mês. Essa quebra da rotina desregula o relógio biológico, trazendo a longo prazo insônia e outros distúrbios prejudiciais à saúde (Mavca, 2011, p. 124).

Trabalhos em turnos com diferentes horários ou no período noturno fixo obrigam o trabalhador a trocar seu período de sono, o que leva a uma desordem temporal do organismo e, ao longo do tempo, a prejuízos à saúde:

A desordem da estrutura dos ritmos circadianos causam mal-estar, fadiga, sonolência, insônia, irritabilidade, prejuízo da agilidade mental, desempenho e eficiência. O sono diurno é prejudicado pelas condições ambientais não favoráveis, como iluminação, ruídos e acontecimentos domésticos, modificando a distribuição das fases do sono e interferindo em sua propriedade restauradora (Campos \& Martino, 2004, p. 416).

Outras consequências, no longo prazo, citadas por Campos e Martino (2004), são os distúrbios severos e persistentes do sono, como fadiga crônica e síndrome psiconeurótica (ansiedade e depressão crônica).

Dependendo do esquema de turnos, podem enfrentar dificuldades de convivência com familiares e amigos, além da relativa impossibilidade de participar de outros compromissos regulares, caminhando para o isolamento social (Moreno, Fisher, \& Rotenberg, 2003, p. 37).

Portanto, devido aos horários incomuns de trabalho, o indivíduo pode enfrentar dificuldades em se relacionar socialmente, já que seu período de trabalho contraria os horários "estabelecidos" pela sociedade. 
"Terei tempo de cuidar da minha saúde, algo difícil na rotina de outras profissões". Essa assertiva também é problematizada pelo jogador brasileiro Carlos Mavca, que a relativiza. Este, por seu conhecimento de causa, afirma que a rotina de um grinder acaba provocando uma vida sedentária e de pouco convívio social que podem afetar alguns jogadores. Ele relata, inclusive, casos de grandes jogadores brasileiros que chegaram a entrar em depressão e ter problemas de saúde até aprender a lidar com essa rotina. Em seu relato sobre a rotina de trabalho, ele crê que ela:

...pode (e deve) ser balanceada com atividades esportivas e sociais, mas ainda assim o grind regular trará efeitos colaterais como a LER (Lesão por Esforço Repetitivo), problemas de visão, postura da coluna etc., que outras profissões similares também trazem. Pior ainda para quem joga em sites menores, pois não há tempo nem a possibilidade de ir "rapidinho" ao banheiro, pois não há, por exemplo, breaks sincronizados (Mavca, 2011, p. 130).

Podemos analisar essa atividade rotineira, repetitiva e de longa duração em uma assimilação com o trabalho taylorizado. Desse modo, autores que estudam a saúde do trabalhador se questionam sobre o bem-estar biopsicossocial, a ausência dele em algumas atividades laborais e as condições básicas para que ele se estabeleça. Em se tratando da forma de trabalho descrita acima, percebe-se que as atividades são exercidas em um campo restrito e heterocontrolado. E, contrariamente ao que é proposto por teóricos (por exemplo, Christophe Dejours), para se conquistar saúde a partir do trabalho, as atividades não permitem uma autorregulação e liberdade como a fantasia propagandeia.

Creio que para o bem-estar físico é preciso a liberdade de regular as variações que aparecem no estado do organismo; temos o direito de ter um corpo que tem vontade de dormir, temos o direito de ter um corpo que está cansado (o que não é forçosamente anormal) e que tem vontade de repousar. A saúde é a liberdade de dar a esse corpo a possibilidade de repousar, é a liberdade de lhe dar de comer quando ele tem fome, de fazê-lo dormir quando ele tem sono, de fornecer-lhe açúcar quando baixa a glicemia. É, portanto, a liberdade de adaptação. Não é anormal estar cansado, estar com sono. Não é, talvez, anormal ter uma gripe, e aí vê-se que isso vai longe. Pode ser até que seja normal ter algumas doenças. O que não é normal é não poder cuidar dessa doença, não poder ir para a cama, deixar-se levar pela doença, deixar que as coisas sejam feitas por outro durante algum tempo, parar de trabalhar durante a gripe e depois voltar (Dejours, 1986, p. 4).

"Tenho um trabalho criativo e dinâmico, pois o poker está em eterna evolução". Nesse momento, Mavca, amparado por um realismo-pessimismo, afirma incisivamente: "MESMO ASSIM, VIRAMOS ROBÔS" (Mavca, 2011, p. 130).

O jogo, por mais que seja dinâmico e evolua constantemente, consiste em repetir tarefas muito simples (analisar ranges, fazer cálculos, tomar decisões e clicar, clicar, clicar em botões). Claro que outras profissões também são assim, mas acredito que, após alguns anos, um jogador on-line se "cansa" muito mais rápido do que faz no dia a dia do que um advogado, por exemplo. É como se ele acabasse virando um "robô" (Mavca, 2011, p. 130).

As decisões passam a ficar menos específicas e criativas, já que se tratam (na maior parte do tempo) de repetições de situações que o sujeito já viu milhares de vezes. Sendo assim, Mavca (2011) propõe que:

A chave para fugir dessas repetições e dessas pressões todas é o equilíbrio. Às vezes, precisamos descansar o corpo e a mente, fazendo outras atividades físicas ou mentais. Tirar pequenas férias e fazer viagens com a família ou passeios com outras pessoas fora do ambiente do poker também pode ajudar a dar uma relaxada. Buscar dias específicos para jogar e para sair com amigos ou namorada é essencial (p. 131).

Nos últimos anos, mostrou-se, embora os trabalhadores há muito tempo o soubessem, que, quando uma tarefa é regular, fixa, imutável, repetitiva, é muito perigosa, causando ou podendo causar muito mal. O trabalho em linhas de montagem é um exemplo típico de coisas que estão bloqueadas e iguais durante todo o tempo, idênticas o tempo todo. Pois bem, cremos 
que se pode mostrar que, mais uma vez, é a variedade, a variação, as mudanças no trabalho que são as mais favoráveis à saúde. Cremos que a primeira aquisição desse ponto de vista, que vem da fisiologia, conduz a que se conceba toda a vida como movimentos, bem como a que se assegure, antes de tudo, a liberdade desses movimentos (Dejours, 1986).

Em cash games, sentiu fome, cansaço, vontade de ir ao banheiro, começou o jogo na televisão, ou sua namorada quer ir ao cinema, é só desligar o computador e pronto! Se tiver um infarto durante um torneio, não há nada que possa fazer, pois suas fichas permanecerão ali. $\mathrm{O}$ jogador Paul "Eskimo" Clark teve um infarto enquanto jogava, e suas fichas ficaram lá até ele ser eliminado blinded out ("morto pelos pingos"). Em cash, qualquer imprevisto, é só sair e voltamos outra hora. Escolhemos nossa mesa e assento, algo impossível num torneio. Cash games também são menos frustrantes do que torneios, pois um bom jogador tende a ganhar na maioria das sessões, enquanto nos torneios você só fica feliz se atinge uma grande premiação, ou seja, sentese frustrado a maior parte do tempo (Mavca, 2011, p. 131).

Todavia, apesar dos benefícios atrelados à maior autonomia proporcionada pelo cash game, essa modalidade apresenta também algumas desvantagens, de acordo com os jogadores. É que normalmente é muito mais enfadonho do que os torneios, logo que os blinds não sobem e há muito menos fichas em jogo. Para exemplificar, atentemos à fala de Mavca (2011, p. 131) quando este traz aspectos desvantajosos da referida modalidade em um paralelo com a prática do jogo a partir de torneios:

Não haverá grandes adrenalinas ou corridas para levar o pote, não haverá eliminações e conquistas. Tomou uma bad beat? É só recarregar seu buy in. Não haverá aquela bolha da mesa final ou a premiação gigantesca. Isso pode fazer você se distrair e não jogar seu A GAME. A rotina é muito mais parecida todos os dias do que a rotina de MTT. Você não vai fazer o seu mês numa única mesa, ou numa única mão, enquanto uma boa premiação de torneio pode resolver a vida de muitas pessoas.

Pudemos notar que as modalidades desenvolvidas do jogo em um paralelo entre torneios e cash games apresentam tanto vantagens (por exemplo, autonomia e flexibilidade para uma e possibilidade de ganhos mais representativos "subitamente" para outra) quanto desvantagens. Nesse ponto, o jogador deve realizar um balanço e encontrar a modalidade a ser exercida que lhe permita maior satisfação, realização e adaptação às suas condições físicas, emocionais e sociais.

\section{A socialização pelo jogo profissional}

O coletivo de trabalho, de acordo com Gaulejac (2007), não é mais portador de laços estáveis. Não funda mais um sentimento de pertença na duração. Não é mais o suporte essencial da identidade social. $\mathrm{Na}$ atual moral do trabalho, as identidades profissionais desaparecem, as pertenças a um "corpo" profissional se tornam obsoletas, a mobilidade não permite mais se instalar duravelmente em um grupo de trabalho. $O$ coletivo não realiza mais sua função de mediação entre o indivíduo e a empresa. Em caso de conflito, ele não é mais o lugar em que se decidem as formas de resistência, as estratégias de luta, a elaboração de reivindicações. Ele não representa mais um elemento central de solidariedade e de proteção. As injunções de flexibilidade, como os sistemas de avaliação individualizados, reforçam a competição e não tanto a colaboração.

O exemplo de rompimento do aspecto afetivo, mesmo dentro dos sistemas organizados pelo próprio trabalho (aqui no caso do poker), pode ser diagnosticado na fala recrudescida e cheia de racionalidade instrumental exposta abaixo:

Após cada sessão, você deve escrever a menor situação que lhe incomodar, e então postar essas coisas nos fóruns. Mantenha os seus olhos abertos para a resposta. É claro, haverá alguns idiotas que farão gracinhas, mas quem se importa? Você está no negócio para ganhar dinheiro. Se você 
quisesse fazer amigos, estaria no Match.com. Não se preocupe com os otários (Schmidt, 2012, p. 45).

Os fóruns, que poderiam ser espaços para a construção do laço social, do coletivo de trabalho, da solidariedade e do reconhecimento, são esvaziados de seu potencial e os sujeitos passam a extrair apenas o desenvolvimento técnico - extirpando qualquer propósito subjetivador.

A partir de um segmento extraído do livro $O$ poder das organizações, podemos traçar outro rico paralelo:

...o indivíduo fica isolado, serializado e atomizado. Ele não tem relação pessoal privilegiada em relação ao todo; sua afetividade se difunde num vasto conjunto e se fixa na organização. Todos se tratam por você, se chamam pelo primeiro nome; as relações são impregnadas de cordialidade, mas "na TLTX não se fazem amigos". Lançado numa competição desenfreada, onde cada um joga suas próprias cartas, é difícil usar de uma solidariedade orgânica entre os membros fundamentada em interesses comuns e na partilha de condições similares (Pagès et al., 1987, p. 124).

Sendo assim, Schmidt (2012) reflete sobre as relações interpessoais que podem surgir dentro da virtualidade do jogo. Realizando um balanço, notamos que sobra superficialidade e perversão e falta em desenvolvimento humano e social. Quando o jogador se pergunta: "conversar ou não conversar?", podemos ver reflexões que constroem este cenário que vem sendo descrito:

Tenho uma sensibilidade semelhante em ligar o bate-papo nas mesas que estou jogando. $O$ diálogo pode ser hilário e até informativo. Mas, para equilibrar, há uma quantidade de fofocas de escritório, que significam distração. Reconhecidamente, adicionar distração ao seu pequeno negócio não é lógico. Qualquer tipo de conversa pode roubar a sua atenção. Junte à equação o fato de que A) você tirou dinheiro dessas pessoas, e B) é um fórum anônimo, e você terá uma receita de energia negativa. Às vezes ligarei o bate-papo só por diversão, e encontrarei umas 100 pessoas tentando conversar comigo. Vinte podem ser profissionais me desejando boa sorte naquele dia, ou me dizendo que veem os meus vídeos. Outros 20 dirão que esperam que eu tenha outro ataque cardíaco, ou simplesmente que me odeiam. É difícil tirar algo de positivo disso (p. 113-4).

Em um paradigma utilitarista, cada ator procura "maximizar suas utilidades", ou seja, otimizar a relação entre os resultados pessoais de sua ação e os recursos que a isso dedica. A preocupação com a utilidade é facilmente concebível em um universo em que as preocupações com a eficiência e a rentabilidade são constantes. É preciso ser sempre mais eficaz e produtivo para sobreviver. A competição é considerada como um dado "natural", ao qual é preciso adaptar-se bem.

Em texto escrito para a revista Card Player, em outubro de 2009, Leo Bello administra algumas sugestões relativas ao campo da sociabilização no mundo do poker. Ele advoga uma imersão no aspecto relacional como favorecedor e, mais do que isso, básico à imersão e sustentação neste campo.

Faça networking: se relacione, conheça pessoas que trabalham com o poker. Troque ideias, se apresente, participe e ajude. Lembre-se de ser humilde diante de quem está começando e ser respeitoso com seus colegas de profissão. Não consigo conceber um único motivo para você se isolar nesse esporte. Mesmo para manter seus adversários próximos e conhecê-los melhor, é preciso se socializar. Nestas horas, lembre-se do ensinamento de Sun Tzu: mantenha seus amigos por perto, e seus inimigos ainda mais perto. Agora, se você quiser realmente prosperar, procure fazer o máximo de amizades possível. Neste mercado, no qual o que se espera do profissional são longas jornadas, dias e dias viajando atrás dos melhores torneios - muitas vezes em outros países -, ter amigos próximos alivia bastante a solidão. Além do mais, é muito melhor ser respeitado e visto com carinho pelos colegas de profissão do que ser tido como uma pessoa indesejável. Os jogadores de poker tendem a ter dificuldades em controlar o ego. As vitórias e o dinheiro no bolso levam a sensações de poder e de conquista. Controlar a arrogância e o ego e ser humilde são atitudes importantes nesse esporte (Bello, 2009, s/p). 
Uma estratégia peculiar da gestão na contemporaneidade edifica-se, conforme Pagès et al. (1987) e Gaulejac (2007), entre outros, a partir da sustentação de um discurso que busca menos atingir o superego das pessoas (que é o responsável pelo zelo da lei), como ocorria na ética do trabalho nas organizações modernas (Weber, 2008), do que seu id (instância que simboliza a fruição e o prazer imediato). Esse discurso da gestão, flutuando no "ar rarefeito" dos valores humanos na atualidade, incita a fantasia do sucesso fácil, do ganho imediato e da esperteza dos melhores. Nessa "fraqueza" da ética do trabalho (Bendassolli, 2007; Sennett, 2002), as pessoas anseiam poder "subir na vida" tão rápido quanto um gesto frenético na bolsa de valores. E evidências não faltam para, um caso em um milhão, comprovar a existência dessa porta, que foi aberta pela nova economia (é o caso de alguns profissionais no mundo do poker que obtiveram sucesso meteórico e que, por sua evidência, sustentam a fantasia de milhões, como o emblemático Chris Moneymaker $\left.{ }^{9}\right)$. Então, o discurso gerencial é o discurso do princípio do prazer. E o que isso acarreta para a formação social? Para o laço societal?

Na "ausência" do pacto edípico para a consolidação do pacto social (Pellegrino, 1987), hipotetiza-se que o indivíduo estabelece um "pacto narcíseo" e os sujeitos passam, assim, a não terem mais "dívidas" com a civilização ${ }^{10}$; isto é, os indivíduos não precisam lhe prestar contas, tampouco a civilização os exige. E qual é a consequência disso? Liberdade?! Sim, mas muito relativa - ou então a um altíssimo custo. Mas o que mais pode ser observado e para o que devemos atentar ou nos preocupar é a desorientação. Na fragilidade do pacto, o indivíduo é entregue a si mesmo e a seu fluxo pulsional. Sendo assim, na labilidade ética (no caso aqui descrito), o sujeito vive à deriva na necessidade de conquistas, sucesso e realização de desejos de maneira constante e infinita, logo que não se encontra preparado/tolerante à frustração e fracasso (que são possibilidades prementes em uma sociedade da competição, mas que, devido às características de formação subjetiva na atualidade, são grande fonte de sofrimento aos indivíduos). "O mal-estar de hoje, seja ou não na sociedade de gestão, é um sinal de que o pacto civilizacional, nesse sentido psicanalítico, vem sendo rompido" (Bendassolli, 2007, p. 13).

O social só funciona, de acordo com Bendassolli (2007), na base da falsificação, da idealização e da hipocrisia. Ele se nutre de ilusões, estereótipos, slogans. Não pode ser de outra forma. A esperança de uma sociedade em que os homens se saciem da verdade é tão falaciosa quanto aquela de uma sociedade em que as pessoas "se saciem de amor", utopia que provoca o sorriso irônico de Freud em sua obra O mal-estar na civilização.

Não podemos vislumbrar uma sociedade em que as relações entre as pessoas sejam, enfim, verdadeiras. Para Bendassolli (2007), enganar-se a si a ao outro, consciente ou inconscientemente, é algo que está na raiz das relações humanas. Assim, os mitos, as ideologias, as religiões, a falsa consciência de si, a impossibilidade de olhar a realidade de frente, "de encarar de frente o abismo" (Castoriadis) continuarão a fazer a lei.

Mas e quando tudo isso está exacerbado? A ilusão, o falseamento, a inverdade como forma de sobrevivência. Como se estabelece o social? Vejamos um depoimento de como a falsidade se estabelece na ética mercadológica do jogo como questão de sobrevivência e depois pensemos em seu potencial civilizatório:

Eu sempre deixo o bate-papo ligado quando jogo heads-up (...) Se estiver jogando contra ele em heads-up, isso quer dizer que ele provavelmente é um oponente mais fraco, então definitivamente quero esta ação. E se este jogador for embora é porque não o mantenho se divertindo, à vontade, então irei conversar com ele. Não quero que ele se vá, então o encorajarei, e quando ele perder, direi, "Oh, camarada. Sinto muito. Esta foi difícil". Isso pode deixá-lo mais propenso a ficar (Schmidt, 2012, p. 114).

Abaixo, se encontram mais alguns relatos teatrais que denotam as características histéricas e perversas dos jogadores em exercício profissional. Os parágrafos subsequentes

9 O amador Chris Moneymaker conseguiu se classificar jogando pela internet para uma competição e faturou, sozinho, US\$ 8,9 milhões em 2003.

10 Para detalhamento dessas dívidas, ver Freud em O mal-estar na civilização (1930/1996). 
retratam estratégias que se desenvolvem em um campo ético virtual que está pautado pela competitividade e sobrevaloriza os aspectos da dissimulação, da esperteza e da sedução.

Muitas vezes, numa mesa de poker, você estará jogando com pessoas que não o agradam, ou com desafetos. O importante é ser educado, sem precisar se socializar com seus oponentes, mas saber respeitá-los e jogar o jogo, tirando suas fichas gradativamente. É um negócio ruim se você afugentar os jogadores ruins - não importa que você goste deles ou não como pessoa. Você não precisa ter um instinto assassino para ser vencedor. Você quer que os fishes se sintam confortáveis e, às vezes, pode até mesmo oferecer uma "desculpa" por alguma carta de sorte ao seu favor (Mavca, 2011, p. 158).

O mesmo autor/jogador continua sua explicação sobre a ética matadora cool (Enriquez, 2000) que se desenvolve no e pelo jogo:

...vamos supor que você tenha feito um nut flush no river contra um jogador inexperiente que você sabe ter uma sequência e, muitas vezes, você optaria em dar um check raise, mas você resolve sair apostando, como se dissesse: "Olha, eu tenho o flush". Ainda que você perca um pouco de expectativa nessa mão, consegue manter o jogo amigável, mantendo-os na mesa. Quando eles perderem com o flush nuts deles para seu full house, lamente junto com eles a grande infelicidade e azar que eles tiveram, como se não houvesse nada que eles pudessem fazer a respeito. Da próxima vez em que eles jogarem, não se sentirão incomodados em se sentar com você. Alguns desses sharks que se sentam na mesa de óculos escuros, iPod, e não conversam com ninguém ou não fazem questão de se entrosar com os parceiros estão fadados a serem personas non gratas nas mesas do live. Às vezes, perder uma mão ou outra com potes pequenos em pequenos blefes faz parte do show. Um bom jogador sabe manter o clima de camaradagem, brincar, fazer piadas, mantendo o ambiente amigável e divertido para que as estrelas continuem a distribuir seu dinheiro sem se importar. Em algumas entrevistas para o pokercast (...) alguns jogadores falaram da necessidade de se entrosar com os fishes, para que eles não fiquem tão chateados de ter um sniper na mesa. Se você está jogando com vários jogadores ruins que estão ali, se divertindo e entregando todo o dinheiro deles, então você não vai querer fazer nada que atrapalhe esse "equilíbrio". Você quer que eles continuem felizes ali pelo maior tempo possível, para que você ganhe o máximo possível (Mavca, 2011, pp. 381-382).

Enriquez (2000) já havia enunciado que os tempos não são mais dos profissionais que comandam (de maneira autoritarista), mas daqueles que seduzem, persuadem, exalam charme, animam e sabem jogar com as aparências. Nossa sociedade é uma sociedade onde a aparência triunfa - e, nesse caso, triunfa em prol do gozo narcísico.

\section{Saúde no trabalho para o jogador profissional de poker}

Observemos uma fala que retrata a questão emocional no jogo, revelando as nuances do (des)controle e como isso afeta a vinculação do sujeito com o jogo em seus aspectos técnicos e práticos (jogabilidade e rendimentos), bem como nos aspectos subjetivos (prazer/realização e sofrimento):

Emocionalmente, na internet, fazer uma coisa errada, em uma mão, quando você está jogando cinco ou seis mesas, e não controlar isso, pode levar a prejuízos financeiros de uma semana. Aliás, no jogo como um todo você tem que controlar isso, não pode ficar numa gangorra emocional ao perder ou ao ganhar por que você joga 6 horas por dia, 365 dias por ano e você vai enlouquecer, embora a adrenalina seja a parte boa de toda essa história, e você joga querendo sentir isso, se divertir, embora também sabe que deve sentir aquela adrenalina sendo frio ao mesmo tempo para jogar bem. Saber onde se deve ser calculista, se controlar para não sentir e, ao mesmo tempo, aproveitar tudo, talvez seja um dos mistérios do jogo, por que ceder à emoção pura pode levar a falhas, e não ceder, jogar friamente, torna tudo mecânico e, no fim, chato, né? Aí que é a loucura, porque você tem que se motivar com o desafio, se motivar com a adrenalina do jogo e, ao mesmo tempo, ter frieza para fazer todas as jogadas de forma absolutamente correta, independentemente do momento ou de quem seja seu adversário. $\mathrm{O}$ rush da adrenalina é fundamental para ser bom jogador porque ele motiva, dá o desafio, os riscos, mas controlá-lo também é fundamental porque tem que analisar e ter frieza na hora de fazer o certo, além de se controlar quando você erra ou está no lado negativo da variância (Mangabeira, 2014, p. 113). 
De acordo com Barus-Michel (1997), sob muitos pontos, a eficiência se opõe ao sentido. Aqui, encontramos uma possibilidade para discutir o momento quando o automatismo se instala, quando o sujeito já racionalizou completamente seu modo de jogar e esvazia o aspecto afetivo que produzia sentido e tinha uma grande contribuição na construção subjetiva pelo trabalho enquanto jogador de poker. A transposição do trabalho flexível para o trabalho racionalizado, especializado e rotineiro pode ser exemplificada com a fala de um jogador (Entrevistado 1) que segue: "Aplico muito essa probabilidade, principalmente na internet, onde vira até um jogo mecânico, às vezes, quando você está lá com vinte telas abertas, jogando em vinte mesas diferentes".

A automatização nas tomadas de decisão e a otimização podem ser colocadas em um paralelo crítico com o desinteresse e a perda do aspecto desafiador e surpreendente do esporte (que seriam fontes de estímulo e prazer no trabalho como jogador): de um lado o triunfo da racionalidade instrumental, do outro, um mundo que não tem mais sentido, que parece dominado pela incoerência e pelo paradoxo: "Se você efetivamente gosta muito de jogar Poker, não se torne um profissional, porque tal mudança lhe tirará a alegria e a emoção quando estiver jogando Poker"11.

As estratégias de conquista pervertem os valores de sucesso e transformam a emulação normal da competição em uma busca infernal para ser o primeiro. O essencial não é mais fazer bem, e sim fazer sempre melhor, ganhar sempre mais.

A violência se banaliza, as degradações das condições de trabalho e o desenvolvimento da precariedade tornam-se condições normais da corrida para o desenvolvimento. A sociedade fica sob pressão. A preconização de uma competição generalizada transmite a ideia de que, para ser o melhor, é preciso ser o primeiro, sem se preocupar com as consequências negativas desse princípio: a lutar para permanecer na corrida, a estigmatização dos "perdedores", o hiperativismo, o estresse, a tensão obsessiva do sempre melhor, a demanda insatisfeita de reconhecimento.

A organização do trabalho no poker exacerba o individualismo e a luta dos lugares. Ela exalta o narcisismo e a competição individual. Contribui para alienar o indivíduo na miragem da realização de si mesmo, do sucesso financeiro e profissional. Miragem tanto mais perigosa porque o mergulha em uma corrida infernal para realizar um destino sob o jogo. Os sujeitos creem conquistar poder e autonomia, ao passo que se tornam os servidores zelosos de um jogo que pode "despedi-los" a qualquer momento.

De modo a rematar a reflexão proposta por este tópico, caracterizaremos o jogo (e o jogar) patológico. Mangabeira (2014) retrata, em sua pesquisa, casos de sujeitos viciados não no poker em si, mas em uma forma de jogá-lo, e exemplifica com um caso em especial:

...tinha um jogador famoso, brasileiro, de vinte e poucos anos que se viciou simplesmente em entrar na mesa de poker com dez mil dólares, cinco mil dólares, apostar tudo na primeira mão, e ver quem ganhava, contra outro que também teria apostado tudo. Ele era um dos melhores do Brasil, mas pegava o dinheiro que ele acumulava só para depois gastar dessa forma, na sorte, sem se preocupar com mais nada. E acabou perdendo tudo. Depois, voltou a jogar, voltou a ganhar dinheiro, e perdeu tudo. $\mathrm{E}$ ia assim. $\mathrm{O}$ vício do cara era essa primeira mão, apostar tudo na sorte. A questão, tal qual Roger descreve, é, portanto, menos do poker, e mais do jogador em termos de estar viciado em apostas baseadas na sorte, recriadas na mesa de poker a partir de um artifício que independe das regras sintáticas do jogo em si. Para o suposto viciado, sua maneira de suprir a compulsão tinha no poker apenas um instrumento e não a causa do vício. Paralelamente, Roger posiciona-se ao lado das narrativas que atestam a habilidade como a realidade do jogo, sendo o vício um estado que pode estar em um jogador que trouxe-o para a mesa como uma bagagem adquirida em outro universo, ou seja, um vício colado ao jogador por

1110 razões para não se tornar um jogador de poker, texto de Tomas Keller. Disponível em: <www.rauloliveira.com/blog>. Acesso em: $18 \mathrm{dez} .2013$. 
outros motivos, devido a outras experiências com o mundo do fortuito, do aleatório, e que usa o poker para esse fim, deturpando-o em sua prática "normal", desportiva, não viciante (p. 95).

Um dos jogadores entrevistados apresenta argumentos que se coadunam com o que foi discutido acima. Ele compreende que o jogo pode ser um campo para o exercício do sofrimento e de patologias. Todavia, por processos de racionalização, realiza um enfoque defensivo da organização-poker (perfeita e onipotente) e externaliza os aspectos relativos a qualquer aspecto "falho" na relação com "O" jogo de poker - culpabilizando o sujeito (por sua fragilidade biopsicossocial):

Entrevistador: Em sua opinião, o trabalho como jogador de poker pode promover ou favorecer o desenvolvimento de doenças - sejam físicas, psíquicas ou sociais?

Entrevistado 3: Me diz uma coisa que não pode? Essa é a mania que existe de um grupo que controla as leis e regimentos de uma sociedade, querendo determinar o que é bom ou o que é ruim para os terceiros, e para não parecerem "draconianos" se valem de argumentos sociais, ou de generosidade psíquica, ou física, como se eles fossem mais aptos a cuidar da vida do terceiro, do que ele próprio, sendo que a atitude do terceiro só pode trazer mal a ela mesma. Carrega isso de uma argumentação pífia, via de regra, pra tentar provar que aquele ser humano não vai fazer bem pra ele ao executar aquilo. Eu acho que tem que existir regramento, porque eu não estou falando de uma sociedade livre de regras. O ser humano tem que ser impedido de fazer mal a terceiros, e tem que ter e o máximo possível de informação e conhecimento que aquela sociedade puder dar para ele, para ele tomar as melhoras escolhas para a vida dele e sofrer as consequências, até para ele se ferrar, conscientemente, ou, quão mais consciente ele estiver. Por que eu entro nesse mérito? Porque quando você diz: "Não pode trazer mal para ele?" Quantas pessoas que você conhece que se ferraram porque casaram com a pessoa errada? Era um cara feliz, divertido, solto, pleno, enfim, feliz, e que hoje você sente um cara triste, amargurado, angustiado, porque ele escolheu a pessoa errada para casar. Eu posso liderar uma campanha para impedir as pessoas de casar, concorda? (...) Quantas pessoas você conhece que abriram um negócio, passaram 30 anos juntando dinheiro para abrir seu próprio negócio, e vieram a perder tudo... Então, vamos impedir as pessoas de abrir seus próprios negócios? (...) E eu vou exagerar de propósito, porque as pessoas pularam de ponte... Então temos que parar de construir pontes. Então, o que algumas pessoas tentam me fazer acreditar é que o poker pode trazer mal pra sua vida, portanto nós temos que impedir essa atividade. Tudo pode trazer mal pra sua vida, abrir um negócio, casar. (...) O problema não está na ponte, mas com o que aquele imbecil fez com a ponte. O problema não está no casamento, mas no que aquela relação gerou de danos para aquelas duas pessoas. $\mathrm{O}$ problema não é a instituição poker, o problema é que algumas pessoas tem propensão à "descivilização", eles vão acabar com a sua vida porque vão enfiar no nariz a coisa errada, porque vão enfiar na veia a coisa errada, ou porque vão casar com a pessoa errada, ou porque vão abrir o negócio errado. Eu estou falando do patológico. E aí tem que ter pessoas mais habilitadas do que eu para falar disso, mas tem pessoas que eu sinto que têm propensão a acabar com a sua vida de alguma forma. Comportamento compulsivo de uma forma patológica. O jogo só é mais um elemento para ele escolher. Ela pode pegar um revolver e sair metralhando o cinema, como algumas pessoas já fizeram, ela pode ir para as drogas, ela pode jogar poker, ela pode casar e acabar com a vida dele e da esposa, ele pode ter filho e acabar com a vida psicológica do filho dele. Esses casos patológicos têm que ser tratados de forma patológica, e aí não sou eu quem tem que dizer o que é melhor para eles, porque tem pessoas muito mais qualificadas do que eu. Nos casos não patológicos, é só a gente deixar de ser ridículo e patético de achar que o poker é um elemento transcendental para acabar com a vida de alguém, como não é o casamento, ou seja, se o ser humano estiver na sua saúde mental plena, e é aí que eu quero chegar, o ser humano, fora da sua saúde mental, vai arrebentar com a sua vida com o que ele quiser, e o ser humano na sua saúde mental plena vai ter que lidar o tempo todo com decisões que o empurrem para o bem ou para o mal.

\section{E conclui seu raciocínio:}

...quer dizer que o cara pode montar um negócio e quebrar, bom, mas isso não quer dizer que ele não pode. Vão tirar o direito da sociedade de montar seus próprios negócios? Quebrar faz parte da vida, você pode quebrar montando seu negócio, você pode quebrar na bolsa, você pode quebrar porque gasta mais do que tem, você pode quebrar por endividamento, mas você não 
pode quebrar por poker. Por que? "Porque é baralho. Ah tá, obrigado". O que é que eu vou falar, velho? E eu não tô lutando pra brigar não, eu quero pegar esses $2 \%$ que são... a minha vontade é virar e falar, "vão se tratar", porque nesse caso é uma coisa constatada, que precisa de tratamento, mas faz o seguinte, passe uns 10 anos sem perder nada porque vocês estão atrapalhando. Eu detesto esses caras, entendeu?! Agora, falando de forma pragmática, esses caras me atrapalham, porque eles ficam fazendo besteira da vida deles, só que a besteira que eles fazem da vida, de novo, no casamento, a sociedade joga na conta "ah, é da vida", a besteira que eles fazem na religião, "ah é da vida", a besteira que eles fazem no trabalho 'é da vida', a besteira que eles fazem no poker, aí já falam, "Olha aí, está vendo? É o poker".

Vejamos como se posicionou, de maneira muito semelhante, outro jogador entrevistado quando submetido à mesma pergunta. Ele também apresenta os argumentos defensivos relativos ao aspecto de vulnerabilidade humana ao descontrole e ressalta a fragilidade orgânica e emocional individual que pode afetar a relação desses sujeitos nas relações institucionais nas quais ele se envolve no campo social:

Entrevistado 1: Bom... voltando ao mundo perfeito, né. Se você estudou, se você tem controle do seu bankroll, se você é dedicado... geralmente são esses caras que são lucrativos na vida enquanto jogador profissional de poker. Eu tenho certeza que não influencia. Agora vou comparar novamente: você é um funcionário público, você vai pra boate, chega bêbado cinco horas da manhã e tem que trabalhar as sete. Você vai prejudicar seu rendimento. Vai levar problemas para casa. Vai afetar a família. Eu acho que no poker funciona da mesma forma. Eu também gosto de comparar: ah, o poker vicia, o poker não sei lá o quê..., o cara que bebe a cerveja ali socialmente, bebe uma vez por semana, o cara não vai afetar a vida dele né. Mas aí você pega um alcoólatra. Por causa de um por cento que é alcoólatra você quer proibir a cerveja. Eu vi um estudo que um e meio por cento da população tem tendência ao vício. Isso em cerveja, em jogo, vício em mulher, vício em trabalho, então não é por causa "desse cara" que a gente tem que prejudicar o resto. Então por causa do alcoólatra a gente vai ter que proibir a cerveja. Por causa do maníaco por trabalho então não vai mais poder ninguém trabalhar. Porque é vício, entendeu!? Mas no poker, pô, como é jogo, então isso aí aflora mais. Mas eu acho que é como qualquer outro lugar.

Os argumentos expostos não necessariamente são inverídicos. Contudo, nos preocupamos com como eles podem, na tentativa de legitimar o jogo e o desenvolvimento de uma atividade laboral como jogador nesse mundo, aniquilar uma necessária atenção que deve ser dada a aspectos que envolvem a saúde humana no trabalho. Aspectos estes que podem, sim, estar ligados às características estruturantes relativas à organização e às condições de trabalho que se dão no e por meio do exercício da profissão poker.

\section{Considerações finais}

Para produzirmos um esclarecimento a partir de uma leitura científica e, em especial, empenhada em um campo relacionado à saúde do trabalhador, utilizamos como abordagem teórica e metodológica a Psicossociologia. Como dentro desse campo, bem como em outros campos relacionados à saúde biopsicossocial, os estudos relacionados diretamente ao nosso objeto de pesquisa (relações de trabalho dos jogadores profissionais de poker) eram escassos, estruturamos nossa leitura do fenômeno por meio de um paralelo com as relações de trabalho desenvolvidas a partir da arena política e ideológica de gestão das organizações estratégicas. Esse paralelo nos permitiu ler o cenário que se configura e traçar algumas hipóteses, logo que ambos revelam-se como fenômenos sociais com processos de subjetivação característicos que permitem uma leitura das feições psíquicas, éticas e ideológicas que compõem nossa sociedade, em vista de suas características marcantes, tais como: estímulo à competitividade, ao risco, ao aprendizado contínuo e à solicitação de condutas individualistas que se somam a um encorajamento de vivências embasadas em uma ética "lábil" estruturada sobre traços histéricos e perversos. 
No modelo de gestão estratégica, o objeto de controle tende a se deslocar do corpo para a psique por meio de uma canalização das pulsões que favorece, assim, uma devoção por parte dos sujeitos que atuam nas organizações com modelo gerencialista. Isso se desenvolve porque, no plano psicológico, configura-se um sistema fundado sobre a solicitação do Ideal de Eu exigência de excelência, ideal de onipotência, medo de fracassar e busca de satisfação narcísica. A identificação com a organização e sua idealização suscitam a mobilização psíquica esperada. Sendo assim, cada um vive como seu próprio patrão. Os agentes se autocontrolam, se autoexploram. O poder da organização (seja a empresa estratégica ou o poker) com a qual se identificam lhes permite acreditar em uma onipotência individual - um Eu em incessante expansão -, não encontrando limites. $\mathrm{O}$ indivíduo deve, portanto, consagrar-se inteiramente a seu trabalho, sacrificar tudo pela sua carreira. A exigência de sucesso encontra seu fundamento no desejo inconsciente de onipotência. A organização estratégica oferece uma imagem de expansão e poder ilimitado, na qual o indivíduo projeta seu próprio narcisismo. Tomado, então, pela ilusão de seu próprio desejo, ele é animado pelo medo de fracassar, de perder o amor do objeto amado, o temor de não estar à altura, a humilhação de não ser reconhecido como um bom elemento. $\mathrm{O}$ trabalhador é posto sob uma grande tensão, entre seu Eu e seu Ideal, para o maior benefício da Organização.

$\mathrm{Na}$ fala de um entrevistado, poderemos ver as mediações dominadoras em exercício no mundo fantástico do poker:

Entrevistado 3: ...um punhado de nerd encontrou no poker um espaço para brilhar, porque o poker é cool, poucas atividades conseguem congruir tantas características. Por que a Fórmula 1 é tão apaixonante? Tem mulheres bonitas, tem dinheiro, velocidade, risco de vida, os pilotos são hábeis, corajosos, dedicados, tem vencedor, tem competição, é irreverente, é meio libertário, não é convencional, mas é glamoroso, é luxuoso, ele acontece nos melhores circuitos, tudo isso faz um grande eco, e as marcas vêm em cima, né?! Eu quero estar associado com esses valores, porque aí vêm marcas, estilos, comportamentos. O poker tem muito disso, ele é libertário, é irreverente, ele é até meio bandido, e ao mesmo tempo ele é milionário, é glamoroso, é moderno, inteligente, só que ele é tradicional, os filmes de velho oeste, ou seja, ele tem uma raiz tradicional, histórica, e ao mesmo tempo ele é jovem, é um boné, um óculos escuro, esse novo jogador ele é meio malandro, ele é meio intelecto, e ele é democrático, dá pra se jogar em faculdade, mas ele é glamoroso, dá pra se jogar dentro dos maiores cassinos, com mãos milionárias, e mulher, dinheiro, prêmio, competição, inteligência, estratégia, sagacidade, tudo isso faz o ambiente - só não tem a velocidade, porque o risco de morte lá é o risco de perder tudo aqui.

De acordo com Mangabeira (2014), os três elementos da vida que, por semelhança, explicam o poker, são diretamente risco, dinheiro e emoção. A partir da análise de suas entrevistas, o autor aponta que essas três categorias são aquelas que os jogadores elegem como força de ação motivacional para o jogo e como instrumentos do jogar.

Joga-se por dinheiro e com o dinheiro, para intimidar o adversário - a força das fichas. Joga-se pelo risco, pela dinâmica de arriscar-se, e usando-se o risco para estruturar e medir apostas e valores - odds, variância, bankroll. E joga-se, primordialmente, pela emoção enquanto fim, algo que se quer sentir, e como instrumento do jogo, controlada e meio de dissimulação (p. 135).

A aproximação teórica com o modelo de gestão das organizações estratégicas novamente nos auxilia. Pagès et al. (1987) questionam: de onde vem o "poder" do TLTXiniano [trabalhador da organização estratégica submetida à pesquisa]? De sua inteligência? De suas qualidades pessoais? E, de pronto, respondem: "Todo mundo sabe que não". Nesse momento, os autores argumentam:

Seu poder vem de sua identificação com a TLTX e de um certo número de símbolos que a caracterizam e a alimentam: o salário é um deles, mas também as viagens de avião, o cartão magnético preso à sua lapela, a possibilidade de dizer: "Amanhã eu irei a Tokyo...", "Eu estou chegando do Rio...", "Eu peguei o Concorde três vezes...", a possibilidade de utilizar as máquinas ultrassofisticadas antes do comum mortal... Todos esses símbolos que permitem acreditar todo- 
poderoso... Nós vemos ao estudar a dominação psicológica como este trabalho se prolonga no próprio coração do indivíduo moldando seu aparelho psíquico (p. 111).

Todo esse aparato material, moral, ideológico e psicológico levaria a uma dominação/sujeição dos indivíduos vinculados à atuação profissional nesse campo. Pode ser visível pelas falas dos entrevistados como, entre os motivos de ligação com a empresa e os sentimentos experimentados em seu favor, a admiração por seu poder, sua generosidade e seu sucesso surgem como grandes fatores mobilizadores de sua vinculação. Vejamos uma ilustração disso:

"Confiamos na empresa, isto não se encontra em qualquer lugar, esta admiração de uma funcionária por sua empresa"; "TLTX é uma bela obra, temos orgulho dela, eu acredito nas pessoas que fazem parte dela, ficamos muito infelizes quando a atacam... não se pode exprimir sentimentos negativos"; "Eu sinto certo orgulho ao dizer que trabalho na TLTX" (Pagès et al., 1987, p. 79).

A partir do paralelo, sugerimos que a constante possibilidade de alcance do eu desejado parece constituir a alienação e a passividade do próprio jogador ante a sua realidade; não apenas devido à educação para a aceitação de regras, mas também pelo imaginário lúdico que se estende paralelamente ao cotidiano e que se reafirma em cada jogo. $O$ jogo parece oferecer uma liberdade contraditória, em que, por um lado, o alívio do Eu repercute no todo social, podendo the gerar ordem e prosperidade (Huizinga, 2005), por outro lado, pode aliviar de maneira alienante. Além de poder ser tão efêmera quanto o próprio jogo, a liberdade oferecida por ele pode tanto tornar a realidade minimamente suportável e contribuir para que o sujeito habite nela quanto pode significar a "prisão" do Eu à necessidade permanente de alívio.

A "organização-poker" favorece aos indivíduos a negação da realidade do tempo e da morte. Eles se fantasiam imortais, negando a possibilidade de aniquilação e desaparecimento. $\mathrm{O}$ sistema psíquico se utiliza do mecanismo da "denegação" ("Eu sei, mas apesar disso...") que os "protege" de tomar consciência de suas dificuldades, da finitude necessariamente ligada às suas ações e de seu enfrentamento ao real. A partir da denegação e da captura do ideal de eu do indivíduo, o jogador/sujeito passa a investir a totalidade de sua libido na "organização-poker". Pode-se instaurar, a partir disso, uma relação de servidão-voluntária ou, conforme apresenta Gaulejac (2007), uma submissão livremente consentida substanciada pela dissolução da instância crítica do indivíduo.

O poder passou da esfera econômica às esferas política, ideológica e psicológica. Atua, portanto, como mediador de aspectos mais profundos (inconscientes) dos sujeitos. As relações de poder inseridas no sistema neocapitalista manifestam a sua característica mais fantástica e perversa, penetram nas estruturas da personalidade, manipulam os ideais e os valores. $O$ indivíduo pode viver o jogo de poker, assim como as organizações estratégicas, como uma droga da qual ele torna-se dependente, não podendo se separar. Sugere-se a ele que esse "êxtase químico" é a estrada pavimentada para a felicidade.

O imaginário do sucesso leva cada um a querer ser "o melhor". Ninguém mais fica satisfeito em ser bom e em fazer bem seu trabalho. É preciso fazê-lo melhor, obter uma implicação total. Para ficar mais claro, podemos "traduzir" o postulado básico do modelo de gestão das organizações estratégicas: a situação presente não pode ser satisfatória porque é sempre possível fazer melhor; só que, para haver um ganhador, obviamente deve haver perdedor ou perdedores. A busca de um ideal de perfeição leva a uma competição infinita e, dessa forma, o sucesso torna-se uma obrigação. É a própria condição da nossa existência, já que, na ideologia de gestão estratégica, ou ganhamos ou desaparecemos. Em outras palavras, podemos dizer que ocorre um culto ao desempenho. É preciso ser mais rápido, mais concreto, mais útil e, especialmente, mais rentável.

Tudo o que vem sendo descrito reverbera nos aspectos que são elucidados por Thomas Keller (jogador profissional de poker norte-americano) em um artigo em que ele coloca dez 
pontos negativos sobre os quais uma pessoa deveria refletir antes de querer se tornar um jogador de poker:

1. Poker não permite uma receita regular e certa.

2. Você precisa reservar uma quantia considerável do seu total disponível para enfrentar os inevitáveis momentos de perda, pelo balanço que o jogo impõe às suas reservas.

3. As grandes variações financeiras podem causar grande angústia mental na maioria das pessoas que jogam Poker.

4. A escolha de se transformar num profissional de Poker afeta enormemente suas relações afetivas, com companheiros/as, parentes e amigos íntimos.

5. É quase impossível ou muito caro ser um profissional de Poker e possuir um Seguro Saúde de qualidade.

6. Existem muitas dificuldades em se conseguir empréstimos, ou mesmo créditos para investimento, sendo um profissional de Poker.

7. Desde que você tenha optado por ser profissional de Poker, é muito difícil sair dessa atividade e voltar para um outro trabalho mais tradicional.

8. É muito difícil fazer novos amigos ou mesmo estabelecer relacionamentos íntimos fora do Poker, se você está jogando profissionalmente.

9. Jogando Poker profissionalmente você perde a noção do efetivo valor do dinheiro e do preço das mercadorias e serviços.

10. Se você efetivamente gosta muito de jogar Poker, não se torne um profissional, porque tal mudança lhe tirará a alegria e a emoção quando estiver jogando Poker. ${ }^{12}$

O jogo de poker profissional por si só não deve ser rechaçado. O que é apresentado acima somente deve ser mais um alerta frente à profissão, que se encontra em amplo desenvolvimento e merece total cobertura tanto em seus aspectos jurídicos, administrativos e contábeis quanto no sentido dos saberes empenhados na saúde do trabalhador (como a Medicina, a Psicologia, a Fisioterapia, entre outros), logo que o exercício profissional responsável (envolvendo aspectos de desenvolvimento técnico - tanto do jogo quando de gestão - e preparação física e emocional) vem favorecendo o sustento e, mais do que isso, a construção identitária de diversos indivíduos em todo o mundo. Todavia, o exercício desorientado/desorganizado do jogo pode desencadear prejuízos à saúde física, mental, social e até mesmo financeira. Isso nos reforça a necessidade de que o processo de profissionalização seja clarificado e estruturado. O estigma social ainda é grande, o que dificulta os processos de reconhecimento e, também, de autoafirmação. A dinâmica do risco pode vir a ser deveras desgastante e, por vezes, massacrante. A angústia de morte é uma presença inevitável em um jogo que pode envolver, cotidianamente, a perda como consequência do exercício profissional - o que demanda elevada preparação e continência emocional. $O$ trabalho, em sua maior parte virtual, expõe os sujeitos à necessidade de ajustes em relação ao aspecto sociofamiliar, especialmente quando este se soma a um trabalho que é realizado em âmbitos domiciliares. Demanda que se atente, ademais, à disciplina necessária para o ajuste das jornadas de trabalho, à realidade de trabalho noturno a que os profissionais (principalmente aqui no Brasil) geralmente se submetem para acompanhar o horário norte-americano de maior fluxo nos sites que organizam o jogo. $\mathrm{O}$ trabalho é realizado em condições saudáveis ou precarizadas. A informalidade e o trabalho autônomo podem envolver vantagens, porém, em contraposição, descobertura de direitos trabalhistas e necessidade de um planejamento estratégico para poder gozar de férias, afastamentos por saúde, aposentadoria, entre outros. Tudo isso deve ser levado em consideração por parte dos aspirantes à profissional e encontrar força em sua divulgação e instrumentalização pelo órgão de responsabilidade e representatividade da "categoria" no país, a Confederação Brasileira de Texas Hold'em, que pode expandir seus trabalhos, que se 
concentram, principalmente, nos aspectos jurídicos e administrativos em relação ao jogo, e abranger os aspectos assimilados à saúde dos sujeitos que se relacionam com o poker, em especial aqueles que passam ao exercício profissional do jogo. Esse último fenômeno também merece a atenção dos saberes acadêmicos, visando instrumentalizar o desenvolvimento de melhores estruturas em relação às condições e à organização do trabalho, a fim de que os jogadores que se empenham cotidianamente no exercício profissional do jogo de poker possam gozar de melhor qualidade de vida e saúde no trabalho.

Entrevistado 3: A principal mensagem, que eu tenho falado insistentemente é: joguem com responsabilidade. A grande razão pela qual o poker sofreu tanto preconceito, desde a década de 1950 até aqui, era porque irresponsáveis faziam dele uma fonte de desvio de condução de vida pessoal e familiar. O poker é uma arte bonita, um evento social, esportivo, estratégico. É bonito demais para ser usado de forma tão pequena, de autodestruição, sabe? Para você que quer ser profissional, utilizando o poker para trazer resultados financeiros, minha mensagem é que, se você perceber que não consegue ter resultados nessa dimensão, use o poker para se divertir. $\mathrm{Na}$ internet, utilize-o como entretenimento. Programe o quanto você pode gastar no poker como quem programa um jantar com a esposa ou uma ida ao estádio de futebol. Use o poker de forma competitiva, jogando para se desafiar, para brincar, mas nunca para trazer coisas ruins para você. Sempre que alguém faz isso, afeta todos aqueles que querem viver do poker. Se o poker não puder ser sua profissão, que seja sua diversão, seu esporte.

Na caminhada de pesquisa e escrita ficou revelado, primeiro, que o poker ainda é um campo pouquíssimo explorado nas Ciências Sociais e da Saúde, tendo em vista que a maior parte dos trabalhos sobre o jogo consiste ou em investidas matemáticas sobre probabilidade ou em reflexões sobre jogo patológico; e, segundo, que a amplitude teórica e prática do tema abrese a diversas propostas e ângulos de análise, sem se esgotar em nenhuma delas.

\section{Referências}

Barus-Michel, J. (1997). Clinique du social. In Bulletin du Laboratoire de Psychologie Clinique. Université Paris VII, 25, 5-9.

Bello, L. (2008). Aprendendo a jogar poker: princípios, técnicas $\mathcal{E}$ prática. São Paulo: Martins Fontes.

Bello, L. (2009). Dominando a arte do poker: Profissional vs. Amador. Revista Card Player, 3 (27).

Bendassolli, P. F. (2007). O mal-estar na sociedade de gestão e a tentativa de gestão do mal-estar (prefácio). In V. Gaulejac, Gestão como doença social: ideologia, poder gerencialista e fragmentação social. Aparecida, SP: Idéias $\&$ Letras.

Bjerg, O. (2011). Poker: the parody of capitalism. Michigan: The University of Michigan Press.

Bleger, J. (1998). Temas de psicologia: entrevista e grupos (2 ed.). São Paulo: Martins Fontes.

Campos, M. L. P.\& De Martino, M. M. F. (2004). Aspectos cronobiológicos do ciclo vigília-sono e níveis de ansiedade dos enfermeiros nos diferentes turnos de trabalho. Revista da Escola de Enfermagem da USP, 38 (4), 415-421.

Dejours, C. (1986). Por um novo conceito de saúde. Revista Brasileira de Saúde Ocupacional, 14 (54), 7-11.

Duke, A. (2007). Como ganhei milhões jogando no WSOP. São Paulo: Globo.

Enriquez, E. (2000). O indivíduo preso na armadilha da estrutura estratégica. In F. C. P. Motta \& M. S. Freitas (Orgs.), Vida psíquica e organização. Rio de Janeiro: Editora FGV.

Enriquez, E. (2014). Jogos de poder na empresa: sobre os processos de poder e estrutura organizacional. São Paulo: Zagodoni.

Ewert, A. (1989). Outdoor adventure pursuits: foundations, models, and theories. Columbus: Horizons.

Freud, S. (1996). Além do princípio do prazer. In Obras Completas de Sigmund Freud. Rio de Janeiro: Imago.

Gaulejac, V. (2001). Psicossociologia e sociologia clínica. In J. N. G. Araújo \& T. C. Carreteiro (Orgs.), Cenários sociais e abordagem clínica. São Paulo: Escuta. Belo Horizonte: Fumec. 
Gaulejac, V. (2007). Gestão como doença social: ideologia, poder gerencialista e fragmentação social. Aparecida, SP: Ideias \& Letras.

Giddens, A. (1991). As consequências da modernidade. São Paulo: Unesp.

Giddens, A. (2007). Mundo em descontrole: o que a globalização está fazendo de nós (6. ed.) Rio de Janeiro: Record.

Huizinga, J. (1991). Homo ludens: o jogo como elemento da cultura. São Paulo: Perspectiva.

La Mendola, S. (2005). O sentido do risco (Trad. N. L. Guarinello). Tempo Social, 17 (2), 59-91.

Le Breton, D. (2006). Risco e lazer na natureza. In A. Marinho \& H. T. Bruhns (Orgs.), Viagens, lazer e esporte: o espaço da natureza (pp. 94-117). São Paulo: Manole.

Madeira, M. C. \& Alloufa, J. (1997). Representações sociais e educação: que relação é esta? Anais do IX Colóquio Franco-Brasileiro Educação e Linguagem. Natal: UFRN/Université de Caen.

Maffesoli, M. (2005). O mistério da conjunção: ensaios sobre comunicação, corpo e socialidade. (Trad. J. M. Silva). Porto Alegre: Sulina.

Mangabeira, C. (2014). Um minuto para aprender, uma vida para dominar: as poéticas do jogo de poker. Tese de doutorado. Universidade Federal do Rio de Janeiro.

Marinho, A. (2008). Lazer, aventura e risco: reflexões sobre atividades realizadas na natureza. Revista Movimento, Porto Alegre, 14 (2), 181-206.

Mavca, C. (2011). Poker: a essência do Texas Hold'em - estratégias para se tornar um vencedor. Rio de Janeiro: Elsevier.

Mendes, A. M. (2007). Psicodinâmica do trabalho: teoria, método e pesquisas. São Paulo: Casa do Psicólogo.

Moreno, C. R. C., Fischer, F. M., \& Rotenberg, L. (2003). A saúde do trabalhador na sociedade 24 horas. São Paulo em Perspectiva, 17 (1), 34-46.

Oliveira, A. L., Berthoud, C. M. E., Begliomini, A. R., Coppola, R. G., \& Rangel, T. C. (2006). O trabalho noturno e suas repercussões na saúde e na vida cotidiana de trabalhadores metalúrgicos do Vale do Paraíba no Estado de São Paulo. Revista Psicologia Organizações e Trabalho, 6 (2), 65-84.

Pagès, M., Bonetti, M., Gaulejac, V., \& Descendre, D. (1987). O poder das organizações (Trad. M. C. P. Tavares \& S. S. Favatti). São Paulo: Atlas.

Pellegrino, H. (1987). Pacto edípico e pacto social. In L. A. Py et al. (Orgs.), Grupo sobre grupo. Rio de Janeiro: Rocco.

Schmidt, D. (2012). O poker como negócio: onde termina o hobby e começa o business. Belo Horizonte: Raise Editora.

Schwartz, G. M. (2002). Emoção, aventura e risco: a dinâmica metafórica dos novos estilos. In M. S. Burgos \& L. M. S. Pinto (Orgs.), Lazer e estilo de vida (pp. 139-168). Santa Cruz do Sul, RS: EDUNISC.

Sennett, R. (2002). A corrosão do caráter: as consequências pessoais do trabalho no novo capitalismo (Trad. M. Santarrita). Rio de Janeiro: Record.

Swarbrooke, J. et al. (2003). Turismo de aventura: conceitos e estudos de casos (Trad. M. P. Toledo). Rio de Janeiro: Elsevier.

\section{Endereço para correspondência \\ guilhermin@hotmail.com, franciscohashimoto@gmail.com}

Recebido em: 27/01/2017

Revisado em: 21/07/2017

Aprovado em: 24/07/2017 